\section{E-LOGOS}

ELECTRONIC JOURNAL FOR PHILOSOPHY ISSN 1211-0442

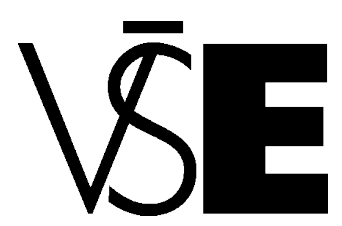

University of Economics

Prague

\title{
'Black Conservatism': The \\ Philosophy of Thomas Sowell
}

Jack Kerwick

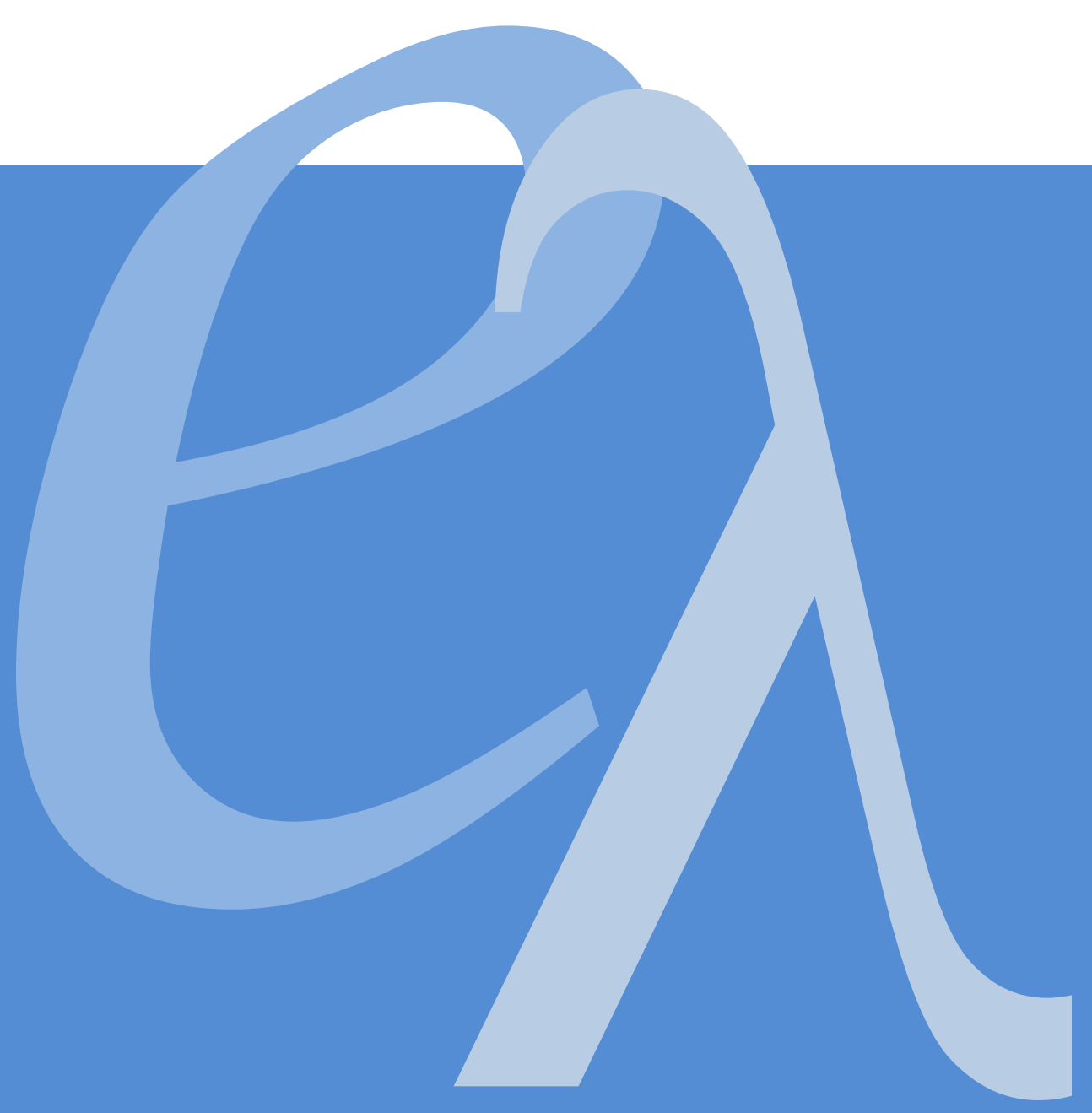




\begin{abstract}
In this paper I explore the concept of "black conservatism" by focusing specifically upon the writings-including his analyzes of racially oriented issues-of the contemporary economist Thomas Sowell. I argue that while there is no such thing as "black conservatism" in the sense of a political philosophical orientation supposedly distinguishable from other types of conservatism, Sowell is the paradigmatic instance of a black thinker whose thought is located solidly within the intellectual tradition of classical conservatism. To this end, I show that the conceptions of human rationality, morality, and the state underlying Sowell's thought converge with those held by such notable representatives of the conservative tradition as Edmund Burke and Michael Oakeshott, with particularly close attention paid to accentuating similarities between Sowell and the latter. It is from the interstices of this conservative intellectual tradition that I abstract Sowell's philosophy of race.
\end{abstract}

\title{
Keywords
}

Conservatism, race, Sowell's philosophy of race, rationalism, Burke, Oakeshott 


\section{Introduction}

For all of the talk of it in recent decades, the notion of a "black conservatism" is like few others in our political universe in that in spite of being mired in ambiguity, it invariably intrigues even while it repels: in the popular imagination, the idea of a black conservative is virtually oxymoronic, for blacks, it is thought, are unfailingly "liberal"; yet once its self-contradictory character is revealed to be an illusion, the intensity of the praise that he elicits from his admirers is matched only by that of the scorn visited upon him by his critics. His detractors impute to the black conservative a blindness to the extent to which "racism" accounts for many of the most pressing ills afflicting contemporary blacks in America, and his black critics are particularly adamant on this point. ${ }^{1}$ But does this characterization of the black conservative do him justice?

My purpose here is threefold. First, since it is as impossible for a distinctive intellectual style to subsist independently of its individual contributors as it is for a language to subsist independently of its users, I relieve "black conservatism" of the confusion that has engulfed it by focusing upon the thought of its most impassioned and articulate representative: Thomas Sowell. Second, in showing that Sowell's epistemological, ethical, and political philosophical conceptions coincide almost seamlessly with those of conservative theorists generally, and the English philosopher Michael Oakeshott specifically, I argue that he is located solidly within a tradition of what has been called "classical conservatism." ${ }^{2}$ Finally, I contend that it is not Sowell's "obliviousness" or "insensitivity" to "racism" that informs his philosophy of race, as his critics allege, but, rather, his endorsement of this older tradition that derives its identity in no small measure from the Rationalism in response to which it originally emerged and to which it has always been steadfastly opposed.

This paper is divided into two sections. In the first, I contextualize Sowell's thought by situating it within the conservative intellectual tradition to which it belongs. In the second, I show how Sowell's conservative orientation informs his views on racial issues.

\section{II.}

Thomas Sowell was born in Charlotte, North Carolina in 1930. At the age of nine, he and his family moved northward to Harlem, where Sowell came of age. He eventually dropped out of high school and joined the United States Marine Corps. When his service with the military ended, Sowell entered Howard University. Not long afterward, he transferred to Harvard, where he majored in economics. Upon graduation, Sowell embarked upon graduate school, and some years later, he completed the doctoral program in economics at the University of Chicago. In the 
intervening years, Sowell has taught at several prestigious institutions, including Cornell, Columbia, and Stanford, while cementing his reputation as a preeminent scholar of the history of economic thought. He has long since abandoned teaching, having become, in the 1960's, thoroughly disenchanted with what he perceived to be an increasingly politicized academy. In addition to having worked for a time in the public sector, Sowell has spent the last couple of decades at the Hoover Institution, where he has brought his training in economics to bear upon issues, like racerelations, that haven't traditionally been treated in accordance with conventional economic concepts. At one time a Marxist, Sowell had a political conversion during the sixties when he began to realize that the idealistic assumptions of his youth could not withstand scrutiny. He gradually gravitated away from the political left and toward conservatism. ${ }^{3}$

What is conservatism? Familiarity with those writings commonly identified with classical conservatism discloses it to be a distinct intellectual tradition by virtue of a loose but steady constellation of formal suppositions and themes concerning the natures of knowledge, morality, and politics shared by its proponents. ${ }^{4}$

There are inescapable limitations on what any individual person can know, much less consciously know. Much, and perhaps most, knowledge is inarticulate, encapsulated in social traditions that have endured centuries, in some cases. All human conduct is made possible by the tradition within which it originates and unfolds. A person's understanding of his world and his relationship to it arise from the tradition or traditions to which that person belongs. From this standpoint, the reason of any individual is constituted and, thus, limited by, the complex tradition to which that individual belongs. What this means is that there is no such thing as Reason as such, an unencumbered, naked, and virtually unlimited power of rationality at least potentially accessible to all people in all places and times, but always a rationality embedded in a culturally specific nexus of practices. As Edmund Burke famously said:

We are afraid to put men to live and trade each on his own private stock of reason; because we suspect that this stock in each man is small, and that the individuals would be better to avail themselves of the general bank and capital of nations, and of ages. ${ }^{5}$

Twentieth century economist and social theorist F.A. Hayek makes the same point. Hayek cautions us against committing "the fatal conceit," which is "the idea that the ability to acquire skills stems from reason." Rather, he informs us, "it is the other way around: our reason is as much the result of an evolutionary selection process as is our morality." It is our moral traditions that "make possible the growth of reason and those capabilities associated with it." 6 But such traditions "are not justifiable in terms of the canons of traditional theories of rationality." 7 In other words, our moral traditions can never admit of explicit justification, for "the process of selection that 
shaped customs and morality could take account of more factual circumstances than individuals could perceive..." It is for this reason that Hayek concludes, and here he is at one with Burke who two centuries earlier affirmed "wisdom without reflection and above it," that "tradition is in some respects superior to, or 'wiser' than, human reason." 8

In his famous essay, "Rationalism in Politics," Michael Oakeshott elucidates further this conception of reason or knowledge. He calls it "practical knowledge," but by this he means knowledge rooted in tradition. Practical knowledge "exists only in use, is not reflective and...cannot be formulated in rules." ${ }^{9}$ Oakeshott tells us that since practical knowledge's "normal expression is in a customary or traditional way of doing things, or, simply, in practice," it "can neither be taught nor learned, but only imparted and acquired." 10 Neither Oakeshott nor any other conservative denies the reality of "propositional knowledge." Rather, conservatives insist that propositional knowledge is supplemented by and, more importantly, parasitic upon another type of knowledge, what Oakeshott calls "practical" or "traditional" knowledge, a knowledge that is disclosed and used only in conduct and which defies express articulation.

Sowell embraces the conservative reading of the human condition, calling it, alternatively, "constrained"11 and "tragic."12 He joins Burke, Oakeshott, Hayek, and any number of other conservative theorists in rejecting without equivocation the atavistic conception of knowledge typical of rationalists. According to the constrained vision, Sowell informs us,

any individual's own knowledge alone is grossly inadequate for social decision-making, and often even for his own personal decisions. A complex society and its progress are therefore possible only because of numerous social arrangements which transmit and coordinate knowledge from a tremendous range of contemporaries, as well as from the even more vast numbers of those from generations past.

On this account, knowledge is "predominantly experience."13

The experience to which he alludes is not the experience of any individual, but "the social experience of the many, as embodied in behavior, sentiments, and habits," 14 the "traditions which evolve from the day-to-day experiences of millions in each generation..." 15 Sowell often refers to these traditions as "cultural" or "systemic processes," and he speaks to the perennial conservative theme of "second nature" when he says that knowledge-the "multiplicity of experience too complex for explicit articulation" 16 - is "distilled over the generations in cultural processes and traits so deeply embedded as to be virtually unconscious reflexes..." 17 This, he asserts, is what Burke meant when he referred to "wisdom without reflection."

Conservatism's "constrained" conception of individual knowledge-its insistence that the conscious knowledge of any given individual or group of individuals is 
miniscule relative to the "bank and capital of nations and ages," as Burke put it accounts for its sympathy with a particular model of the modern state, or what is usually (but misleadingly) referred to as "society." In what follows, I will use these terms interchangeably. On this model of it, the state is conceived along the lines of what Oakeshott calls a "civil association" and Hayek describes as a "spontaneously evolved order," by which he means a "free society." Because the knowledge of each individual is severely constrained and presupposes an intricate and open textured tradition of activity the many complex nuances of which, having been unconsciously imbibed, defy explicit articulation, conservatives staunchly oppose the rationalistic notion that society can be compelled to comport with something on the order of a blueprint of supra-temporal ideals. It is this skepticism, in other words, that the conservative holds with respect to both the rationalist's belief in a tradition-neutral, virtually omni-competent Reason, and the perfectionist aspirations that it inspires, that lead the conservative to value individuality and plurality, the two chief characteristics of civil association.

Oakeshott's exposition of "civil association" is as follows. A civil association, he explains, is association with respect to "laws," or "non-instrumental rules of conduct." Laws are "non-instrumental" because "they are not rules that specify a practice or routine purporting to promote the achievement of a substantive purpose, " for the members of civil association "have no common substantive purpose." Laws are similar to (though not exactly like) "the rules of a game which are directions, not about how to win but about how to play, or the rules of public debate, which do not tell a speaker what to say and are wholly indifferent to any particular conclusion." He continues: "These non-instrumental rules specify and prescribe, not choices to be made or actions to be performed, but conditions to be subscribed to in choosing and acting."18 The rules of civil association can never be considered with respect to their tendency "to promote or hinder the achievement of a common substantive purpose," for in a state conceived as a civil association, "there is none."19 In a civil association, citizens are regarded as individuals who, either severally or in concert with others, are engaged in numerous self-chosen activities. Individuality and plurality are the chief characteristics of a society conceived as a genuinely civil association. ${ }^{20}$

Oakeshott contrasts this conception of society with its rationalist rival: enterprise association. On the model of an enterprise association, the state exists for the sake of bringing to fruition some goal or ideal at least implicitly held to subsist independently of and in advance of the state and in accordance with which its activities are to be evaluated. The terms of an enterprise association can never be anything other than policy prescriptions, orders or commands that derive their significance and justification from their conduciveness in promoting the telos that is sought. In the state conceived as an "enterprise association," all members are 
comrades or partners who must divest at least some of their resources in time, money, and energy to realize the end or plan that is their "common good."

Sowell advocates what Oakeshott calls "civil association," although this is not the idiom that he employs. He contrasts what he calls "traditional justice," on the one hand, with what he describes as "social justice" and "cosmic justice," on the other. We will examine his account of the latter below, but first we must turn to his account of the former. Traditional justice requires that "rules and standards" be "equally applicable to all..." (9). ${ }^{21}$ From this standpoint, "justice or injustice is characteristic of a process" (8 emphasis original). ${ }^{22}$ Sowell submits the example of a criminal trial as an illustration of traditional justice.

A defendant in a criminal case would be said to have received justice if the trial were conducted as it should be, under fair rules and with the judge and jury being impartial. After such a trial, it could be said that "justice was done" - regardless of whether the outcome was an acquittal or an execution. Conversely, if the trial were conducted in violation of the rules and with a judge or jury showing prejudice against the defendant, this would be considered an unfair or unjust trial - even if the prosecutor failed in the end to get enough jurors to vote to convict an innocent person.

Sowell concludes: "In short, traditional justice is about impartial processes rather than either results or prospects" (9). ${ }^{23}$ Although he speaks of justice as a "process," Sowell is of like mind with Oakeshott who denied that in a civil association, a nonpurposeful order, there was any place for substantive considerations of political justice. The "rules and standards equally applicable to all" with respect to which Sowell understands genuine political justice, Oakeshott would say do nothing more (or less) than specify "adverbial conditions" to be observed as citizens engage in their own self-chosen pursuits. As long as government does everything reasonably possible to insure that these conditions are met, justice is done.

Sowell argues against the rationalist project of deliberately enlisting all of society's members in the service of some ostensibly transcendent ideal (Oakeshott's "enterprise association"), like Justice - what he calls "cosmic justice." He targets specifically those rationalists who believe that Justice requires the imposition of a substantive condition of material equality, or at least the amelioration, if not the complete elimination, of "'undeserved inequalities.'" The proponents of this view, most of whom have long since abandoned the notion that God is responsible for the numerous statistical disparities of which society is riddled, "are often driven to personify 'society' in order to re-introduce concepts of moral responsibility and justice into the cosmos, seeking to rectify the tragic misfortunes of individuals and groups through collective action..." 24 Ideas of "social justice" or "cosmic justice" that figure prominently among rationalists of all sorts neither Sowell nor the conservative tradition from which he speaks finds intelligible. "Yet," he continues, the "collective 
action" to which rationalists of this sort are committed "is not limited to correcting the consequences of social decisions or other collective social action, but extends to mitigating as well the misfortunes of," for instance, "the physically and mentally disabled..." Such misfortunes are viewed as not arising from society exactly, but "from the cosmos." "It seeks to produce cosmic justice..." 25 The main problem with this position, Sowell remarks, is that "the knowledge required to sort...out intellectually, much less rectify...politically" these inequities "is staggering and superhuman." ${ }^{26}$ In other words, the goal of cosmic justice is unattainable.

Sowell holds with other conservatives that individuality and plurality are imperiled by the quest for "social" and "cosmic justice," attempts to make society into an enterprise association. He criticizes this "moralism," "the general implicit assumption of a single scale of values applicable to all." 27 Sowell cites the work of John Rawls as illustrative of this line of thought. Rawls insists that as a matter of justice, social and economic goods be "arranged" to the benefit of "the least advantaged." Sowell points out that "the bland and innocuous word 'arrange'" covers "a pervasive exercise of power necessary to supersede innumerable individual decisions," a power wielded in order "to make people stop doing what they want to do and do instead what some given principle imposes." 28 When social justice - a specific value or set of values - is imposed upon the citizenry, "freedom as the general preservation of options gives way to the imposition of one group's preferred option." 29 In other words, "more' justice in such a world means more forcible imposition of one particular brand of justice-i.e., less freedom." 30

According to Sowell, rationalists' desire for imposing upon the state the character of an enterprise association arises from the false assumption that it is possible to deliberately design a social order that is remotely as efficient in its functioning and, ultimately, beneficial for society as the order that has emerged as the result of millions upon millions of human beings, past and present, habitually, unselfconsciously, following tradition. The conservative vision to which he subscribes, however,

puts little faith in deliberately designed social processes, since it has little faith that any manageable set of decision-makers could effectively cope with the enormous complexities of designing a whole blueprint for an economic system, a legal system, or a system of morality or politics.

Rather, it "relies instead on historically evolved social processes and evaluates them in terms of their systemic characteristics - their incentives and modes of interaction - rather than their goals or intentions." ${ }^{31}$ Conservatives, in fact, don't think that it is at all meaningful to speak of the "goals or intentions" of "historically evolved social processes" at all. Sowell cites language as the "purest example" of 
such a process, and just as no one would contend that language has an end or purpose, at least not one specifiable in advance, so no one should think any differently with respect to any other "spontaneously evolved order," to use Hayek's words.

In The Vision of the Anointed, Sowell says of language that it "arises out of gropings, accidents, experiences, and historical borrowings and corruptions of other languages," and that its "richness, complexity, and subtleties...have arisen systemically, from the experiences and interactions of millions of ordinary human beings, not from a top-down 'plan' formulated by some elite." Of course, grammarians and linguists are able to reflect upon language in its current condition and codify some of its aspects, but the principles and structures that their investigations reveal are not given in advance of the language but are, rather, its offspring. Specialists can never give us anything more than an abridgement of the language that they seek to explain. "From time to time, linguistic practices are codified or modified by intellectuals, but this is an incidental part of a vast drama." 32 Similarly, political theorists, whether they recognize it or not, do not discover eternal principles or ideals that range over all cultural traditions; rather, the principles or ideals upon which they exposit are abbreviations of their tradition. Political or ideological principles no more precede political activity than grammatical principles precede language.

It is precisely because of their painful awareness of the severe limitations on individual human knowledge that conservatives are invariably and exceptionally cautious about pursuing change. It isn't that conservatives are "opposed to" change. It was "the patron saint" of conservatism, Burke, who said that "A state without the means of some change is without the means of its conservation." Rather, conservatives recognize that every change necessarily involves loss, or a "trade-off," as Sowell puts it.

Oakeshott writes that for the conservative, "change...appears always, in the first place, as deprivation." 33 It is not without reservation that he will seek to innovate, for "innovating is an activity which generates not only the 'improvement' sought, but a new and complex situation of which this is only one of the components." In short, "there is no such thing as an unqualified improvement." 34 It is for these reasons that conservatives prefer those innovations that most "resemble growth" over those that strike as being "imposed upon the situation," and changes that are slow and gradual rather than those that are rapid and abrupt.

Sowell endorses this conservative disposition toward change. He notes two possible conceptions of change that he associates with two mutually incompatible "visions." The conservative vision with which he sympathizes he refers to as the "constrained" or "tragic" vision. From this perspective, every change is a "trade- 
off." In contrast, there is what Sowell calls the "unconstrained vision" or "the vision of the anointed," the vision of rationalists. In The Vision of the Anointed, Sowell is to the point: "There are no solutions; there are only trade-offs." ${ }^{35}$ All that we have to work with are "trade-offs that still leave many desires unfulfilled and much unhappiness in the world." Thus, "what is needed...is a prudent sense of how to make the best trade-offs from the limited options available," as well as "a realization that 'unmet needs' will necessarily remain..." Sowell cautions against "attempting to fully meet these needs seriatim," for it "only deprives other people of other things, so that a society pursuing such a policy is like a dog chasing its tail." He asserts that "particular solutions to particular problems are far less important than having and maintaining the right processes for making trade-offs and correcting inevitable mistakes." 36

Conservatism affirms a tradition-centered theory of knowledge. The knowledge of any individual is an inheritance from numerous generations of people from throughout the ages, distilled in the tradition(s) to which that individual belongs. Much of this knowledge is unreflective, and even unconscious, and defies explicit excogitation. Because of the severe limitations on individual rationality, because knowledge is largely a matter of (unreflective) practice, conservatives are extremely skeptical of all rationalist plans to usurp "traditional justice" with "social" or "cosmic justice," to replace "plurality" with "homogeneity" by imposing upon society the character of an "enterprise association," rather than a "civil association," a "designed," as opposed to a "spontaneously evolved order." All such rationalistic attempts to "perfect" circumstances presuppose a faith in the possibility of "solutions" that conservatives find incorrigibly naïve. The intractable, unrelenting fallibility of human knowledge guarantee that genuine solutions to social problems will forever be beyond our grasp: there are only "trade offs." I have attempted to show here that any adequate characterization of Sowell's thought must locate him within the tradition of classical conservatism, for he shares with its exponents a tradition-centered conception of rationality and, with it, a staunch aversion to Rationalism. By examining the relationship between his conservative commitments and his analyzes of racially oriented issues, I will now argue that, his critics' accusation to the contrary notwithstanding, Sowell's philosophy of race is informed, not by any insensitivity to the harms of "racism," but, rather, a painful recognition of the harms of Rationalism.

\section{III.}

The tradition-based (or culture-based) model of politics that conservatives advance differs fundamentally from those models endorsed by rationalists of different stripes. In "Rationalism in Politics," in a footnote, Oakeshott refers to "the politics of Nature" and "the politics of Reason," two equally rationalistic doctrines 
that, while distinct, overlap in "exceedingly complicated" ways. He says that fundamentally, they share in common a rejection of "civilization," or "all human achievement more than about a generation old." 37 Put another way, regardless of the specific claims made on behalf of each model, or of any of the internal varieties of which they both admit, neither the politics of Nature nor the politics of Reason allots any space to "tradition" ("culture" or "civilization"). This needs to be borne in mind when analyzing Sowell's philosophy of race.

Individuals are not equal; neither are races. The equality to which I refer is not the equality of which Christians have spoken when they have declared, paraphrasing Saint Paul, that all are equal in God. The "moral" or "spiritual" equality of human beings is not in question here. Culturally speaking, neither individuals nor the racial and ethnic groups to which they belong are equal. Proponents of what Sowell calls "the civil rights vision" attribute statistical disparities to "discrimination," or "racism." That is, they assume that such social regularities are deliberately designed by "society." In contrast, others account for these statistical disparities in terms of the genetic advantages and disadvantages of the favored and disfavored groups, respectively. Both positions are expressions of the two forms of rationalism just mentioned, for whether disparities are alleged to be the product of nature or the devious rational design of racists, neither gives the slightest consideration to the role that tradition plays in accounting for these phenomena. Conventional racial orthodoxy holds that these are the only two possibilities. Sowell rejects them both on the grounds that they are rationalistic constructs that abstract from the complex of concrete contingencies and relativities that produce the statistical disparities in question.

Sowell asserts that the civil rights vision "is not only a moral vision of the way the world should be in the future, but also a cause-and-effect vision of the way the world is today." 38 There are three central and particularly controversial premises at the heart of the civil rights vision that he mentions, but for the moment, I want to focus only on two of them. The first is that "statistical disparities in incomes, occupations, education, etc., represent moral inequities, and are caused by 'society.'" 39 The second is that "belief in innate inferiority explains policies and practices of differential treatment, whether expressed in overt hostility or in institutional policies or individual decisions that result in statistical disparities." Sowell writes:

Ironically, the innate inferiority doctrine and the opposite "equal representation" doctrine proceed on the same intellectual premise - that one can go from innate ability to observed result without major concern for intervening cultural factors. Unexplained residual differences between groups, after controlling for such gross differences as education or parental income, are attributed by one vision to discrimination and by the other to genetics. 
He concludes that "there are apparently no other reasons for differences in skill or capability other than discrimination, which is illegal, or innate inferiority, which is rejected. Or so it appears in the civil rights vision." 40

Neither the prevailing racial orthodoxy nor the much less popular doctrine of innate inferiority is adequate to account for inter-racial inequalities. In stark contrast to these abstract approaches, Sowell's conservative study situates the inequalities that obtain between white and black Americans within an expansive context that is at once historical and inter-national. Let us turn to the first principle of the civil rights vision: discrimination is the inevitable culprit of statistical disparities between racial groups.

Before critiquing it, Sowell notes that this principle implicitly relies upon at least three presuppositions that, though perhaps plausible, are nevertheless demonstrably false.

The first, and apparently most obvious, is that discrimination leads to adverse effects on the observable achievements of those who are discriminated against, as compared to the discriminators or to society in general. The second assumption is that the converse of this is equally true - that statistical differences signal, imply and/or measure discrimination. This assumption depends upon a third unspoken premise-that large statistical differences between groups do not usually arise and persist without discrimination.

This last assumption must figure in the civil rights vision, Sowell remarks, for if substantial statistical disparities between groups can occur in the absence of discrimination, "then discrimination takes its place as only one cause among many and inferences from statistical disparities lose their validity as evidence." This state of affairs would in no way disprove the existence of discrimination, but it would undermine "the convenient statistical barometer..." 41

In truth, though, "statistical disparities are commonplace among human beings," a fact for which there are "many historical and cultural reasons..." 42 The Chinese in southeast Asia, Jews in numerous societies throughout the world, East Indians in Africa, southeast Asia, and various areas in the western hemisphere, Italians in South America, and the Japanese in the United States are among some of the racial groups that have flourished in the midst of being systematically discriminated against by the majority populations with which they have had to co-exist. The Chinese, for example, "for several centuries" in southeast Asia, had "been - and continues to bethe target of explicit, legalized discrimination" in a variety of areas, from an assortment of occupations and institutions of higher learning to which they are denied entry, to property bans and restrictions. Still, in Malaysia, Indonesia, Vietnam, Thailand, and the Philippines, the Chinese, who constitute no more than $5 \%$ of the population of all of Southeast Asia, "owns a majority of the nation's total 
investments in key industries." 43 In spite of the fact that they "encountered persistent and escalating discrimination, culminating in their mass internment during World War II," the Japanese in the United States, by as early as 1959, "had about equaled the income of whites," and a decade later, "Japanese American families were earning nearly one-third higher incomes than the average American family." 44

Sowell concedes that given the unique history of blacks in America, black Americans are a "special case." However, he argues that even the history and circumstances of this group defy the principle in question. In Latin America, blacks "have not been subjected to as rigid and severe segregation, oppression, or violence as blacks in the United States. Yet blacks in Brazil...are economically farther behind whites than are blacks in the United States..." 45 Furthermore, while slavery is among the most invidious forms of discrimination, and in spite of the frequency with which "the legacy of slavery" argument is made to account for the multiple pathologies found among contemporary black Americans, Sowell points out that the evidence undermines this argument. With respect to the high illegitimacy rate and number of single parent headed households among black Americans, Sowell writes: "Most black children, even under slavery, grew up in two-parent households. A teenage girl raising a child with no man present was a rarity among blacks, both during the era of slavery and as late as the 1920's." 46 Crime is another issue.

Few people today are aware that the ghettos in many cities were fare safer places just two generations ago [Sowell wrote this in 1984] than they are today, both for blacks and whites. Incredulity often greets stories by older blacks as to their habit of sleeping out on fire escapes or on rooftops or in public parks on hot summer nights. Many of those same people would not dare to walk through those same parks today in broad daylight. 47

It was not uncommon for whites in the 1930's, believe it or not, to regularly spend evenings in Harlem, often not leaving until late morning hours, when they would hail taxis to drive them to their homes. "Today," Sowell observes, "not only would very few whites dare to do this, very few cabs would dare to be cruising ghetto streets in the wee hours of the morning." He asks rhetorically:

If crime is a product of poverty and discrimination as they [proponents of the civil rights vision] say endlessly, why was there so much less of it when poverty and discrimination were much worse than today? If massive programs are the only hope to reduce violence in the ghetto, why was there so much less violence long before anyone ever thought of these programs? 48

Statistical comparisons between "blacks" and "whites," Sowell observes, trade in interpersonal abstractions as opposed to flesh and blood persons. Each group consists of several subgroups, some of which have virtually nothing but skin color in 
common with the others with which they are conflated. Take West Indians, for instance. West Indians are biologically indistinguishable from American blacks, yet by nearly every social indicia, the two groups are as different from one another as "blacks" and "whites." In Ethnic America, Sowell attributes this to the difference in conduct between them. "West Indians were much more frugal, hard-working, and entrepreneurial. Their children worked harder and outperformed native black children in school," and they "had lower fertility rates and lower crime rates than either black or white Americans." 49 In The Economics and Politics of Race, Sowell elaborates further, telling us that as recently as 1969, West Indian blacks in America earned $94 \%$ of the average income of Americans generally, as opposed to American blacks, who earned but 62\%, and second-generation West Indians "earned 15 percent more than the average American."50 Sowell's point is that the experience of West Indians in America reveals that the appeal to discrimination in accounting for blackwhite inequalities is not only not the foregone conclusion that it is often taken to be, but fails even as an hypothesis, for white racism should prevent both types of blacks from succeeding, given that to a white racist, "all blacks look alike."

However, even focusing on American blacks alone we immediately discover that they comprise anything but a monolithic group. Sowell says that marriage, age, education, and region of residence are just some of the factors that are crucial in determining a range of social phenomena.

As far as back as 1969, black males who came from homes where there were newspapers, magazines, and library cards had the same incomes as whites from similar homes and with the same numbers of years of schooling. In the 1970's, black husband-and wife families outside the South earned as much as white husband-and-wife families outside the South. By 1981, for the country as a whole, black husband-and-wife families where both were college educated and both working earned slightly more than white families of the same description. ${ }^{51}$

Sowell concludes:

Many of the "racial" differences based on gross statistics are shown by a finer breakdown to be differences between people with different values and lifestyles, who are differing proportions of different racial populations. Where the values and lifestyles are comparable, the economic and social outcomes have tended to be comparable. ${ }^{52}$

The second premise of the civil rights vision - that discrimination must be due to a belief in innate inferiority on the part of the discriminators - is just as dubious as the first. Sowell remarks that not only is it the case that "many of the groups most subject to violence have not been generally viewed as innately inferior," but, in fact, they "have been hated precisely because of [their] superior performances as economic competitors." Chinese, East Indians, Jews, and Armenians are some of the 
examples that Sowell cites. He does not deny that the doctrine of innate inferiority has indeed often accompanied the discrimination that has been exercised against black Americans historically, yet he notes that such discrimination does not, as the civil rights vision supposes, necessarily result from a belief in innate inferiority. "Even the enslavement of blacks," Sowell says, "was not the result of a doctrine of innate inferiority." Rather, "this doctrine developed as a rationalization of slavery" after the institution came under increasing criticism in the West, and after "religious rationalizations - enslaving 'heathens' for their own spiritual good - were first used and then abandoned as more slaves became Christians..."53

Sowell sums up, saying that "belief in the innate inferiority doctrine has been neither necessary nor sufficient to explain intergroup hostility, oppression, violence, or enslavement." 54

The third proposition central to the civil rights vision is that it is primarily, if not exclusively, through political activity that "underrepresented" groups are to advance. This is the quintessential rationalist assumption that "social engineering" is desirable. Sowell challenges it, saying that all of the empirical evidence shows that political power is "neither necessary nor sufficient for economic advancement. Nor has eager political participation or outstanding success in politics been translated into faster group achievement." 55 The Chinese in southeast Asia, the Caribbean, and the United States, the Germans in Brazil, Australia, and the United States, the English in Argentina, the Jews in America, Britain, and South Africa, and the Italians in America and Argentina, are among the various groups of people who have prospered economically and socially while steadfastly refusing to participate in politics. ${ }^{56}$ While the Irish did advance through politics, "their rise from poverty was much slower than that of other groups who were nowhere near being their political equals," and in spite of the presence of Irish political machines in many large American cities in the latter part of the nineteenth century, "the great bulk of the Irish populace remained unskilled laborers and domestic servants..." IrishAmerican citizens didn't start to achieve economic prosperity until many years later, when the Irish political machinery began to wane. ${ }^{57}$

In Black Rednecks and White Liberals, Sowell looks at the black American experience. "The civil rights legislation of the 1960's," he says, "may well have been an effect of the rise of blacks, rather than the sole or predominant cause of that rise..." That so many of us believe otherwise, Sowell explains, is due to the fact that black and white "civil rights leaders," motivated by the need "to magnify their own role in racial progress," have labored tirelessly to impress this idea into the popular consciousness. ${ }^{58}$ He notes that while "the Civil Rights Act of 1964 and the Voting Rights Act of 1965 dealt major blows to racial restrictions... and had dramatic effects on the number of black elected officials," economically speaking, "the upward trends 
in black income and occupations that had begun decades earlier simply continued, but at no accelerated rate." 59 Furthermore, "the rise of blacks into professional and other high-level occupations was...greater in the years preceding the Civil Rights Act of 1964 than in the years afterward, and was greater in the 1940's than in the 1950's." 60 For example, $87 \%$ of black families were living in poverty in 1940. By 1960, before the historic civil rights legislation that was to follow a few years later, this rate had fallen to $47 \%$. Although beset by periods of retrogression in race relations - e.g., the post-Reconstruction era in the South, and the imposition of rigid racial restrictions on Northern blacks following the mass migrations of Southern blacks to the North before World War I-black Americans made remarkable economic and educational advances every decade from emancipation onward, but the rate at which such advances occurred were greater before 1960 than afterward.

Sowell's position on the role of politics in society is reflective of his conservatism. Like other conservatives, he views politics as the limited activity of governing, of preserving the legal conditions without which an orderly society is impossible. But the politics of the conservative is what has elsewhere been called "the politics of skepticism." 61 Conservatives, as we have seen, have little sympathy for the idea that government should direct society in the pursuit of some great enterprise or other, for they hold that in a genuinely civil society, whose members are associated to one another in terms of laws that extend equally to all, there is no grand enterprise that can engage the attention and energies of every citizen. It is the model of war, conservatives believe, that is the inspiration for rationalists of all stripes who are determined to transform society into some awesome enterprise association or another, for it is in times of war when the resources of citizens are conscripted and enlisted in the service of an ideal or set of ideals, and it is during such times especially when individuality and plurality pose the gravest threat.

On the issue of black progress, Sowell claims that "the economic advancement of blacks, both absolutely and relative to whites...was due to the individual efforts of millions of black people trying to better their own lives." 62 Blacks were able to flourish "under the most adverse conditions" because of those "little platoons" like family, church, and local community-virtue forming institutions intermediate between the individual and the State that were the products of their cultural tradition. Not only did law do little to facilitate their substantial social gains, it was not infrequently antagonistic to the social well-being of black Americans.

Moreover, Sowell doesn't think that, generally speaking, anyhow, government can achieve substantive satisfactions like equality or the elimination of racism without creating problems at least as great, and usually greater, than those with which it is concerned. Whereas "crusaders like to talk about 'solutions,'” in reality "life is actually one trade-off after another." In the final resort, there is but one 
fundamental question that is the concern of politics: "What are you prepared to give up in order to get what you want?" 63 With respect to "affirmative action," Sowell explains that by overlooking a number of factors, such as differences in age and geographical preference between demographic and racial groups, and attributing the lack of "proportional representation" to discrimination, its proponents have unwittingly harmed the very people whose interests they claim to champion. "Affirmative action" creates special rights that are "costs to the recipients themselves." He writes:

The general unattainability of many quotas means that penalties fall equally on discriminatory employers and nondiscriminatory employers. A discriminatory employer therefore has little to gain by becoming a nondiscriminatory employer, when the characteristics of the target population (age, education, etc.) insure that he will be unable to fill quotas anyway.

\section{Furthermore,}

the ease with which a discrimination case can be made makes minorities and women more dangerous employees to have, in terms of future prospects of law suits if their subsequent pay, promotions, or other benefits do not match those of other employees or the expectations of administrative agencies. 64

There are two other types of cost that preferential treatment policies impose. They increase social tensions and result in a loss of freedom. In Is Reality Optional?, Sowell says that preferential treatment policies, what is referred to as "affirmative action" in the United States, have been practiced in a wide range of countries, from Nigeria to Sri Lanka to New Zealand. In spite of the vast differences between these societies, as well as the differences between the groups who are the recipients of preferential treatment, there are numerous resemblances, the most pervasive of which is the "polarization" that preferential treatment policies produce. In those places where these policies have been in place for longest, like India and Sri Lanka, the social strife has translated into bloodshed. 65

There are two ways that "affirmative action" imperils freedom, according to Sowell. For one, the usurpation of heterogeneity through the imposition of homogeneity that it entails necessarily requires an expansion of governmental power and a corresponding loss of freedom on the part of individuals to make their own hiring decisions. Sowell writes:

Much focus on the desirability of the various outcomes being sought distracts attentions from the fundamental change of processes required to pursue those outcomes. Metaphors about how "society" should "arrange" this or that result evade the institutional reality that 
someone must be empowered to constrict other people's freedom - and thus evade the need to weigh whether the expected value of the result being sought, given the chances of achieving it, is greater or less than the expected value of the loss of freedom that this effort entails 66

The other sense in which freedom is undermined by "affirmative action" concerns the rule of law, which requires that all laws be known or at least knowable in advance of our actions. Yet discrimination, when conceived against the backdrop of affirmative action laws, can have no "clear prospective meaning, such as applying different standards to members of different groups or subjecting some to more onerous processes than others," but "must be defined by retrospective results, whether 'disparate impact' or 'hostile environments'..." Attempts to bring to fruition "equal results or equal prospects, with little or no regard for whether the individuals or groups involved are in equal circumstances or have equal capabilities or equal personal drives," frustrates that mechanism without which a free society, or, for that matter, any stable society, is impossible: the rule of law. Methods to secure substantive equality "cannot operate under general rules, the essence of law, but must create categories of people entitled to various outcomes, regardless of their own inputs" 67 (160).

\section{Conclusion}

In this paper, I sought to clarify the character of what is commonly regarded as "black conservatism" by examining the writings of Thomas Sowell, a thinker widely acknowledged by both friends and foes as the most articulate of its voices and, perhaps, its chief inspiration. By looking at his work and comparing it with that of conservative theorists, including and especially Michael Oakeshott, I demonstrated that Sowell speaks from within a tradition of conservative thought spanning centuries. I argued that it is Sowell's endorsement of the epistemological, ethical, and political philosophical suppositions constitutive of this traditionsuppositions that are radically at odds with those underwriting Rationalism-and not any supposed insensitivity to the harmful effects of "racism" that his critics impute to him, that informs his philosophy of race. 


\section{Endnotes}

1. It is worth observing that this and this alone is essentially the ground from which resistance to the ideas associated with "black conservatism" springs, for they are not so much engaged by their critics as summarily, and vehemently, dismissed. Cornel West's response to "black conservatism" is typical. In spite of his concessions that "racial discrimination" and "white racism" are "spurious" reasons in adequately accounting for "the socioeconomic position of the majority of black Americans," (81-82) he insists that "black conservatism is unacceptable" (83). Yet West never interacts with the argument(s) of any specific black conservatives to justify this verdict. Not long after identifying Sowell's Race and Economics as the catalyst for "the new" black conservatism, West complains that "the new black conservatives assume that without affirmative action programs, white Americans will make choices on merit rather than on race," an assumption, he contends, for which "they have adduced no evidence" (78). The problem with this assertion is that not only hasn't Sowell made this "assumption," he has repeatedly argued against the very concept of "merit." It is true, however, that he has labored indefatigably to show both that "affirmative action" has resoundingly failed to deliver to "disadvantaged" blacks the benefits that they were promised, as well as the remarkable economic progress that blacks have made prior to the creation of "affirmative action" laws, but for these conclusions, and contrary to West's charge, Sowell has indeed adduced a mountainous amount of data. When West doesn't mischaracterize "black conservatism," he impugns what he takes to be the nefarious motives of its adherents, a tactic particularly popular among its black critics. Black conservatives are driven by their "need...to gain the respect of their white peers," (78) a legacy, West says, of "white racism" (79). See Cornel West's Race Matters (New York: Vintage Books, 1994).

2. Black thinkers invariably described as "black conservatives," though they reject the contemporary liberal dogma on race, are not necessarily "conservative" in the classical sense of that term. That neither their defenders nor their opponents have taken the time to delineate the at times significant philosophical differences between them is unfortunate, for these black critics of the political Left compose anything but a monolith, and even when their views on race converge, they are often informed and motivated by beliefs that are not only logically distinct, but, not infrequently, mutually incompatible.

Joseph G. Conti and Brad Stetson have written two studies of what they call "black conservatism." The first is a survey of black scholarly thought, while the second canvasses a range of popular writings. In Challenging the Civil Rights Establishment: Profiles of a New Black Vanguard (Westport: Praeger Publishers, 1993), the focus is on such "black conservative" thinkers as Thomas Sowell, Shelby Steele, Robert L.Woodson, and Glenn Loury. In Black and Right (Westport: Praeger Publishers, 1997), Clarence Thomas, Jesse Lee Peterson, and Larry Elder are among the "black conservatives" discussed. 
3. Sowell recounts these features of his life in his memoirs. See his A Personal Odyssey (New York: Simon \& Schuster, 2000). For a more abbreviated version of some of the same episodes, consult his A Man of Letters (New York: Encounter Books, 2007).

4. That the distinction between the formal and the substantive is anything but hard and fast is something of which I am well aware. Still, to concede this is far from conceding the uselessness of the distinction altogether. For an excellent survey of classical conservative thought, see Jerry Z. Muller's Conservatism: An Anthology of Social and Political Thought from David Hume to the Present (Princeton: Princeton University Press, 1997). Muller makes this point that conservatism can't be understood in terms of the substance of the positions that individual conservatives have taken in different places and times, for "the institutions which conservatives have sought to conserve have varied, the major targets of conservative criticism have changed over time, and conservatism differs from one national context to another." While there are "substantive commitments" common to conservatives, an understanding of conservatism as a coherent intellectual tradition is to be gotten from focus on "an identifiable constellation of shared assumptions, predispositions, arguments," and "metaphors" that collectively "form a distinctive conservative pattern of social and political analysis" (xiii).

5. Edmund Burke. Reflections on the Revolution in France, in The Portable Edmund Burke. Ed. Isaac Kramnick (New York: Penguin Books, 1999), 451-452.

6. F.A. Hayek. The Fatal Conceit (Chicago: The University of Chicago Press, 1988), 21.

7. Ibid., 72 .

8. $\quad$ Ibid., 75 .

9. Michael Oakeshott. "Rationalisn in Politics," in Rationalism in Politics and Other Essays (Indianapolis: Liberty Fund, 1962), 12.

10. Ibid., 15.

11. Thomas Sowell. A Conflict of Visions: Ideological Origins of Political Struggles (New York: William Morrow, 1987).

12. Thomas Sowell. The Vision of the Anointed: Self-Congratulation as a Basis for Social Policy (New York: Basic Books, 1995).

13. Thomas Sowell. A Conflict of Visions: Ideological Origins of Political Struggles (New York: Basic Books, 1995). 40, emphasis original. 
14. Ibid., 42 .

15. Ibid., 41 .

16. Ibid., 45 .

17. Ibid., 45-46.

18. Michael Oakeshott. "Talking Politics," in Rationalism in Politics and Other Essays (Indianapolis: Liberty Fund, 1962), 454.

19. Ibid., 455.

20. Oakeshott explores this issue further in "The Rule of Law," in On History and Other Essays (Oxford: Basil Blackwell, 1983).

21. Thomas Sowell. The Quest for Cosmic Justice (New York: The Free Press, 1999), 9.

22. Ibid., 8 emphasis original.

23. Ibid., 9 .

24. Ibid., 4-5.

25. Ibid., 5 emphasis mine.

26. Ibid., 13

27. Thomas Sowell. Knowledge and Decisions (New York: Basic Books, 1980), 369.

28. Ibid., 331 .

29. Ibid., 369.

30. Ibid., 370 .

31. Thomas Sowell. A Conflict of Visions: Ideological Origins of Political Struggles (New York: William Morrow, 1987), 68.

32. Thomas Sowell. The Vision of the Anointed: Self-Congratulation as a Basis for Social Policy (New York: Basic Books, 1995), 124-125 emphasis mine. 
33. Michael Oakeshott. "On Being Conservative," in Rationalism in Politics and Other Essays (Indianapolis: Liberty Fund, 1962), 409.

34. Ibid., 411.

35. Thomas Sowell, The Vision of the Anointed (New York: Basic Books, 1995), 142.

36. Ibid., 113 emphasis original.

37. Michael Oakeshott, "Rationalism in Politics," in Rationalism in Politics and Other Essays (Indianapolis: Liberty Fund, 1962), 33.

38. Thomas Sowell, Civil Rights: Rhetoric or Reality? (New York: William Morrow and Company, 1984), 14 emphasis original.

39. Ibid., 15.

40. Ibid., 23.

41. Ibid., 16-17.

42. Ibid., 19.

43. Ibid., 20.

44. Ibid., 21.

45. Ibid., 74 emphasis mine.

46. Ibid., 75 .

47. Ibid., 84-85.

48. Ibid., 85 .

49. Thomas Sowell, Ethnic America (New York: Basic Books, 1981), 219.

50. Thomas Sowell, The Economics and Politics of Race (New York: William Morrow and Company, 1983), 107 emphasis mine.

51. Thomas Sowell, The Vision of the Anointed (New York: Basic Books, 1995), 57 emphasis original.

52. Ibid., 58 . 
53. Thomas Sowell, Civil Rights: Rhetoric or Reality? (New York: William Morrow and Company, 1984), 22-23.

54. Ibid., 23.

55. Ibid., 32.

56. Ibid., 30-31.

57. Ibid., 32 emphasis original.

58. Thomas Sowell, Black Rednecks and White Liberals (San Francisco: Encounter Books, 2005), 51 emphasis original.

59. Ibid., 50-51 emphasis original.

60. Ibid., 51 emphasis original.

61. Michael Oakeshott, The Politics of Faith and the Politics of Scepticism. Ed. Timothy Fuller (New Haven: Yale University Press, 1996).

62. Thomas Sowell, Is Reality Optional?And Other Essays? (Stanford: Hoover Institution Press, 1993), 175.

63. Ibid., 96.

64. Thomas Sowell, Knowledge and Decisions (New York: Basic Books, 1980), 259.

65. Thomas Sowell, Is Reality Optional? And Other Essays (Stanford: Hoover Institution Press, 1993), 161-162.

66. Thomas Sowell, The Quest for Cosmic Justice (New York: The Free Press, 1999), 156.

67. Ibid., 170. 


\section{Bibliography}

Appadurai, A. 1991. "Global Ethnoscapes: Notes and Queries for a Transnational Anthropology." In Richard G. Fox (ed.) Recapturing Anthropology: Working in the Present. Santa Fe: School of American Research Press. Pp. 191-210.

Appadurai, A. 1993. "Disjuncture and Difference in the Global Cultural Economy." In The Phantom Public Sphere. Bruce Robbins (ed.) Minneapolis: University of Minnesota Press. Pp. 269-95.

Berry, T. 1988. The Dream of Earth. San Francisco: Sierra Club Books.

Berry, T. 1990. "The Spirituality of the Earth." In Charles Birch, William Eaken and Jay B. McDaniel (eds.) Liberating Life: Contemporary Approaches in Ecological Theology. Maryknoll, New York: Orbis.

Brown, D. A. 2001. "the Ethical Dimensions of Global Environmental Issues," Daedalus Fall: 59-75.

Callicott, J. B. 2001. “Multicultural Environmental Ethics,” Daedalus Fall:77-97. 


\section{E-LOGOS}

ELECTRONIC JOURNAL FOR PHILOSOPHY

Ročník/Year: 2011 (vychází průběžně/ published continuously)

Místo vydání/Place of edition: Praha

ISSN 1211-0442

Vydává/Publisher:

Vysoká škola ekonomická v Praze / University of Economics, Prague

nám. W. Churchilla 4

Czech Republic

13067 Praha 3

IČ: 61384399

Web: http://e-logos.vse.cz

Redakce a technické informace/Editorial staff and technical information:

Miroslav Vacura

vacuram@vse.cz

Redakční rada/Board of editors:

Ladislav Benyovszky (FHS UK Praha, Czech Republic)

Ivan Blecha (FF UP Olomouc, Czech Republic)

Martin Hemelík (VŠP Jihlava, Czech Republic)

Angelo Marocco (Pontifical Athenaeum Regina Apostolorum, Rome, Italy)

Jozef Kelemen (FPF SU Opava, Czech Republic)

Daniel Kroupa (ZU Plzeň, Czech Republic)

Vladimír Kvasnička (FIIT STU Bratislava, Slovak Republic)

Jaroslav Novotný (FHS UK Praha, Czech Republic)

Jakub Novotný (VŠP Jihlava, Czech Republic)

Ján Pavlík (editor-in-chief) (VŠE Praha, Czech Republic)

Karel Pstružina (VŠE Praha, Czech Republic)

Miroslav Vacura (executive editor) (VŠE Praha, Czech Republic) 